\title{
Why do firms appoint former military personnel as directors? Evidence of \\ Ioan interest rate in militarily connected firms in Indonesia
}

Type: Article

\section{Abstract:}

Purpose - Anecdotal evidence shows that a number of military personnel have been appointed as board members by listed firms in Indonesia. Taking advantage of the unique setting of the strong influence of the military in Indonesian politics, the purpose of this paper is to provide direct empirical evidence on the effect of military connections on interest rate for listed firms in Indonesia. Design/methodology/approach - This study uses a sample of 1,818 firm-year observations of firms listed on the Indonesian Stock Exchange (IDX) from 2004 to 2012 and employs Heckman's two-stage regression and Coarsened Exact Matching methods to address endogeneity concerns on the firms' establishment of military connections. Findings - The finding reveals that connected firms significantly enjoy lower interest rates on debt than non-connected ones. These findings are robust to several robustness checks. Research limitations/implications The results of this study should be treated with caution since the proxy of military connections limited only based on board connections. Hence, this may underestimate the results from this study. This research has implications for Indonesia's regulators who are striving to improve accounting information and transparency of militarily connected firms. Originality/value - The results of this study add to the literature that connected firms enjoy preferential benefits provided by the connections through lower interest charges from banks.

\begin{tabular}{|c|l|}
\hline Author & \multicolumn{1}{|c|}{ a) Harymawan I. } \\
\hline Source & Asian Review of Accounting \\
\hline ISSN & 13217348 \\
\hline DOI & $10.1108 /$ ARA-07-2016-0086 \\
\hline Volume (Issue) & $26(1)$ \\
\hline Page & $2-18$ \\
\hline Year & 2018 \\
\hline
\end{tabular}

Keyword:

Bank loan, Developing country, Interest rate, Military connections

Please Cite As:

Harymawan, I. (2018). Why do firms appoint former military personnel as directors? evidence of loan interest rate in militarily connected firms in indonesia. Asian Review of Accounting, 26(1), 2-18. 
URL:

- https://www.scopus.com/inward/record.uri?eid=2-s2.085040034699\&doi=10.1108\%2fARA-07-20160086\&partner|D=40\&md5=16710f1736dc9561940707ebb88ee1b7

- https://www.emerald.com/insight/content/doi/10.1108/ARA-07-2016$\underline{0086 / f u l l / h t m l}$ 